\title{
Tapasztalatok és motiváltság: magyar középiskolások véleménye az egészségvédő programokról
}

\author{
Feith Helga Judit dr. ${ }^{1}$ - Melicher Dóra ${ }^{5}$ - Máthé Gábor ${ }^{2}$ \\ Gradvohl Edina dr. ${ }^{1}$ - Füzi Rita dr. ${ }^{6}$ - Darvay Sarolta dr. ${ }^{7}$ \\ Hajdú Zsófia ${ }^{1}$. Nagyné Horváth Emília ${ }^{8}$. Soósné Kiss Zsuzsanna dr. ${ }^{3}$ \\ Bihariné Krekó Ilona dr. ${ }^{7}$ - Földvári-Nagy Lászlóné Lenti Katalin dr. ${ }^{4}$ \\ Molnár Edit ${ }^{9}$ - Szalainé Tóth Tünde ${ }^{10}$. Urbán Veronika dr. ${ }^{4}$ \\ Kassay Adrienn ${ }^{1}$. Falus András dr. ${ }^{5}$ \\ Semmelweis Egyetem, Egészségtudományi Kar, 'Társadalomtudományi Tanszék, \\ ${ }^{2}$ Képalkotó Diagnosztikai Analitikus és Orvostechnikai Tanszék, ${ }^{3}$ Egészségtudományi Klinikai Tanszék, \\ ${ }^{4}$ Morfológiai és Fiziológiai Tanszék, Budapest \\ ${ }^{5}$ Semmelweis Egyetem, Általános Orvostudományi Kar, Genetikai, Sejt- és Immunbiológiai Intézet, Budapest \\ ${ }^{6}$ Budapest Főváros Kormányhivatala II. Kerületi Hivatala, Népegészségügyi Osztály, Budapest \\ ${ }^{7}$ Eötvös Loránd Tudományegyetem, Tanító- és Óvóképző Kar, Természettudományi Tanszék, Budapest \\ ${ }^{8}$ Kőbányai Bem József Általános Iskola, Budapest \\ ${ }^{9}$ Lisznyai Utcai Általános Iskola, Budapest \\ ${ }^{10}$ Lovassy László Gimnázium, Veszprém
}

\begin{abstract}
Bevezetés: Az egészséggel összefüggő attitúdök leghatékonyabban fiatal életkorokban befolyásolhatók helyes irányba. A fiatal generációk interaktívabb tudásátadási módszertant igényelnének az egészségvédelemmel foglalkozó programokban. Célkitüzés: A szerzők célkitűzése az volt, hogy megismerjék a középiskolás diákok egészségvédő témákkal, programokkal, valamint az iskolai közösségi szolgálattal összefüggő attitüdjeit, tapasztalatait és motiváltságát. Módszer: Az önkitöltős kérdőíves felmérést budapesti és vidéki középiskolások körében végezték $(\mathrm{N}=898)$. Eredmények: A válaszadó középiskolások 44,4\%-ának nem volt egészségvédelemmel foglalkozó iskolai tanórája vagy tanórán kívüli programja. A fóvárosi diákok pozitívabb tapasztalatokkal, a diáklányok sokkal elfogadóbb attitűdökkel rendelkeznek az egészségvédő programokat illetően. Következtetések: Megállapítható, hogy az egyik legfogékonyabb életszakaszban sok fiatal nem vagy csak a hagyományos oktatási módszereken alapuló iskolai tanóra keretei közötti vagy azon kívüli egészségvédelemmel, tudatos betegségmegelőzéssel foglalkozó programokban vesz részt. Orv. Hetil., $2016,157(2), 65-69$.
\end{abstract}

Kulcsszavak: egészségnevelés, középiskolai egészségvédő programok, iskolai közösségi szolgálat, egészségszociológia

\section{Experience and motivation: opinion of Hungarian high school students about health promotion programs}

\footnotetext{
Introduction: Health-related attitudes can be encouraged most effectively at young ages. Young generations would require more interactive methods in programs engaged in health promotion. Aim: The aim of the authors was to get an insight into the attitudes, experience and motivation of youngsters in connection with health promotion programs and the community service work. Method: The questionnaires were filled in by high school students studying in Budapest and in the countryside $(\mathrm{N}=898)$. Results: $44.4 \%$ of the students did not have lessons or extracurricular activities dealing with health promotion. Concerning health promotion programs, youngsters in Budapest had more positive experience, while female students showed a more adoptive attitude. Conclusions: It was concluded that in one of the most susceptible life stages, many youngsters either do not participate in programs dealing with health promotion, or participate in programs that are within the framework of school subjects or extracurricular activities building on traditional teaching methods.
} 
Keywords: health education, health prevention programs in high school, community service work for high school students, health sociology

Feith, H. J., Melicher, D., Máthé, G., Gradvobl, E., Füzi, R., Darvay, S., Hajdú, Zs., Nagyné Horváth, E., Soósné Kiss, Zs., Bihariné Krekó, I., Földvári-Nagy Lenti, K., Molnár, E., Szalainé Tóth, T., Urbán, V., Kassay, A., Falus, A. [Experience and motivation: opinion of Hungarian high school students about health promotion programs]. Orv. Hetil., $2016,157(2), 65-69$.

(Beérkezett: 2015. október 20.; elfogadva: 2015. november 12.)

\section{Rövidítések}

ESPAD = European School Survey Project on Alcohol and other Drugs; IKSZ = iskolai közösségi szolgálat; KLIK = Klebelsberg Intézményfenntartó Központ; KutDiák = Kutató Diákok Mozgalma; TANTUdSZ = Tanulj, tanítsd, tudd! ifjúsági egészségnevelő program

Az új évezred küszöbén a „magatartás évtizede” elnevezéssel illették a XXI. század első évtizedét, mivel az életminőség meghatározó elemei a helyes életmód és egészség-magatartás tényezőiben keresendők [1]. Régóta ismert, hogy az egészség fogalma a biológiai, a pszichológiai és a szociális vonatkozások egymásra kölcsönösen ható tényezőinek eredőjeként írható le, így az egészség ma már sokkal többet jelent a betegség puszta hiányánál. Evidencia, hogy az egészséggel összefüggő attitűdök, a megfelelö életmód leghatékonyabban a minél fiatalabb életkorokban befolyásolható helyes irányba.

Sajnos, a magyar fiatalok körében még mindig kifejezetten magas számos kockázati magatartás előfordulása, nemzetközi összehasonlító kutatások szerint némelyik növekedést mutat, sőt meg is haladja az európai átlagot. Így például az ESPAD (European School Survey Project on Alcohol and other Drugs) adatai szerint a kutatásban részt vevő 16 éves magyar fiatalok 37\%-a gyújtott rá a kérdésfeltevést megelőző 30 napban, az európai átlag $28 \%$ volt. A Magyar Ifjúság 2012 kutatás adatai a négy évvel korábbi eredményekhez képest ugyan javulást mutattak néhány területen, azonban még mindig nem kielégítő a helyzet, hiszen például az eredmények szerint a fiatalok 27\%-a napi szinten dohányzik [2].

A serdülők táplálkozási szokásai (reggelizési szokások, táplálék minősége, gyakorisága) és ezzel összefüggésben a túlsúlyosság és alultápláltság prevalenciája, a szájhigiéné, a fizikailag aktív (intenzív testedzés) szabadidős tevékenység mértéke nem kielégítő, ugyanakkor nagyon sok időt töltenek tévénézéssel, és a tanulást nem támogató számítógép-használattal [3].

Az egészségkárosító magatartás kialakulásában a családi háttér meghatározó, mint ahogyan a szülői és a kortársminta is. Egy hazai kutatás bizonyította, hogy a dohányzó szülők gyermekei kisebb eséllyel vélték hatékony dohányzást csökkentő módszernek szüleik, tanáraik nem dohányzó példamutatását. Ez alátámasztja a dohányzást elutasító szülői attitűd nagyobb jelentőségét [4].
A tanulmányunkban ismertetett kutatásunk kiindulópontját a „TANTUdSZ - Tanulj, tanítsd, tudd!” ifjúsági egészségnevelő program jelentette. A hiteles tudásátadást, a kreativitást s a gyakorlatorientáltságot képviselő TANTUdSZ program az egészségtudományi, valamint a pedagógusképző karok hallgatói, továbbá a fiatalabb korosztályok közötti interakciót segíti elő [5].

Kvantitatív kutatásunk egyik célkitűzése az volt, hogy megismerjük a középiskolás diákok egészségvédő témákkal, programokkal összefüggő attitűdjeit, tapasztalatait. A TANTUdSZ programhoz kapcsolódó vélemények és attitűdök felmérésén túl vizsgáltuk a középiskolai diákok visszajelzése alapján a nemzeti köznevelésről szóló 2011. évi CXC. törvényben előírt iskolai közösségi szolgálattal (IKSZ) kapcsolatos tapasztalatokat, motiváltságot.

\section{Minta és módszer}

Kvantitatív kérdőíves felmérésünket budapesti és vidéki 9.-10.-11. (illetve, ahol a 13. évfolyam az érettségizó osztály, ott belevéve a 12.) osztályos középiskolások körében végeztük 2015. május-június hónapokban. A felmérésekben 898 diák vett részt. Csoportos önkitöltős módon budapesti középiskolák, valamint egy veszprémi középiskola diákjai válaszolták meg a kérdéseket, ugyanakkor KutDiák hálózatban részt vevő középiskolásokhoz is eljuttattuk a kérdőívet. Az iskolában történő kérdőívkitöltéshez a felkeresett iskolákhoz tartozó KLIK tankerületi igazgatók hozzájárulását előzetesen megkértük, és jóváhagyásukat megkaptuk.

A kérdéseket egy multidiszciplináris szakmai csapattal szoros együttmúködésben dolgoztuk ki. A 31 zárt és 4 nyitott kérdést tartalmazó kérdőív próbatesztelése megtörtént. A kutatás a szociodemográfiai kérdéseken túl a 2014/2015-ös tanév egészségvédő, prevenciós iskolai tanórai vagy tanórán túli programjaira, az önkéntességre és iskolai közösségi szolgálatra vonatkozó attitűdökre és tapasztalatokra, valamint a tervezett TANTUdSZ program sajátos módszertanához kapcsolódó véleményekre terjedt ki.

A kérdőívet elektronikus alapon kitölthető, egyszerű formába programoztuk, kitöltése önkéntesen és anonim módon történt.

Az adatok elemzését az SPSS 22.0 statisztikai programcsomag eszközeinek használatával végeztük. A meg- 
oszlási vizsgálatok mellett a változók közötti kapcsolatok mérésére a Pearson-féle $\chi^{2}$-próbát $(\mathrm{p}<0,05)$ alkalmaztuk.

\section{Eredmények}

A kutatásban részt vevők 56,0\%-a lány, 44,0\%-a fiú volt. A kérdőív kitöltésekor a diákok 18,2\%-a nyelvi előkészítőbe, 30,5\%-a 9., 26,1\%-a 10., míg 25,3\%-a 11. évfolyamra (öt évfolyamos képzésben 12. évfolyamra) járt. Átlagéletkoruk 16,3 életév volt. Mindössze 9 diák jelölt be szakközépiskolát, döntő hányaduk gimnazista volt. Beazonosíthatóan 14 középiskola diákjai töltötték ki a kérdőívet, 128 fö (14,3\%) nem nevezte meg az iskoláját. A válaszadók több mint négyötöde budapesti (69,0\%) és Pest megyei (15,9\%) iskolába járt. Lakóhely tekintetében 46,4\% Budapesten, 6,9\% megyeszékhelyen, 28,3\% városban, 14,4\% községben és 4,0\% tanyán élt.

A válaszadó középiskolások 44,4\%-ának nem volt egészségvédelemmel, betegségmegelőzéssel foglalkozó iskolai tanórája vagy tanórán kívüli programja.

$\mathrm{Az}$ alacsony részvételi arány ellenére mindössze 17,0\% nem hisz abban, hogy ezeknek a programoknak pozitív hatása lehet a diákok jövőjére, életvitelére vonatkozóan. Az utóbbi kijelentésre adott válaszokat statisztikailag bizonyítható módon nem befolyásolta, hogy volt-e a diáknak ilyen tanórája vagy tanórán kívüli foglalkozása ( $\mathrm{p}=$ 0,132). Ugyanakkor, akik inkább hisznek ebben, azoknak a nagyobb hányada $(58,3 \%)$ részt vett ilyen foglalkozáson.

Az egészségvédelemmel, betegségmegelőzéssel foglalkozó iskolai tanórára vagy tanórán kívüli programra adott válaszok összefüggést mutattak $(\mathrm{p}=0,029)$ az évfolyammal: leginkább a 11. évfolyamosok jelezték $(64,8 \%)$, hogy volt ilyen tanóra vagy foglalkozás, a többi évfolyam esetében megközelítőleg csak a diákok fele. Jellemzően az iskolai tanóra keretei között foglalkoztak ezekkel a témákkal, de a 2014/2015-ös tanévre vetítve öt vagy annál több tanórát e válaszadók esetében is csak $15,8 \%$ jelölt be. Még rosszabb az arány a tanórán kívüli foglalkozások esetében, hiszen a válaszadók közel fele (46,7\%) egyáltalán nem vett részt ilyenen. Az iskola településtípusa (fóvárosi/nem fóvárosi) egyértelműen befolyásolta a tanórán kívüli egészségvédő programokra adott válaszokat $(\mathrm{p}<0,001)$. A budapesti középiskolások 58,2\%-a, míg a nem budapesti középiskolások 45,2\%-a jelezte, hogy legalább 1-2 tanórán kívüli egészségvédő témájú foglalkozása volt. Hét vagy annál több foglalkozást jelző diákok 78,4\%-a volt fóvárosi, míg csak 21,6\%uk volt nem fóvárosi középiskolás. A tanórai keretek közötti prevenciós témák tekintetében viszont nem volt statisztikailag bizonyítható különbség a válaszadók között $(\mathrm{p}=0,132)$.

A válaszadó diákok 44,7\%-ának tapasztalatai szerint ezek az egészségvédő, betegségmegelőző programok nem interaktívak (nincsenek közös feladatok, játékok). Vagyis a megkérdezettek kevesebb, mint egyharmada

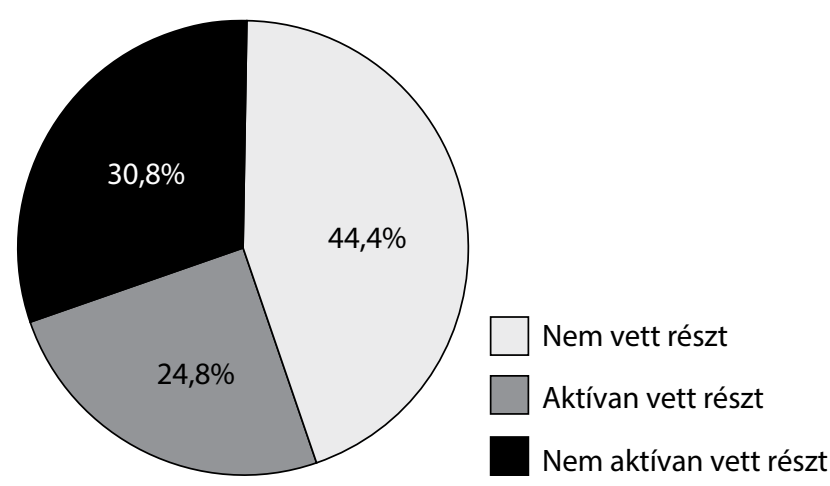

1. ábra $\mid$ Egészségvédő témával foglalkozó programokon való részvétel a programok interaktivitása szempontjából $(\mathrm{N}=898)$

$(30,8 \%)$ vett részt interaktív módon ezeken a programokon (1. ábra).

205 diák (a válaszadók 41,1\%-a) szerint az előadónak nem is fontos, hogy aktívan részt vegyen a programban, 64,3\% szerint ezeknek a programoknak a többsége „csupán egy előadás". A válaszadók háromnegyedének tapasztalata alapján $(75,7 \%)$ ezeket a programokat jellemzően felnőttek tartják, pedig a teljes minta mindössze egyötöde $(21,9 \%)$ utasítaná el, ha egyetemisták tartanának ilyen jellegű foglalkozást. A többség - a fentiek ellenére - inkább pozitív tapasztalatokkal távozik ezekről a foglalkozásokról, bár csak minden tizedik diák (10,6\%) jelezte, hogy kizárólag pozitív tapasztalatai vannak, és sokat tanul ezekból a programokból. 71,1\% nem értett egyet azzal az állítással, hogy ezeknek az egészségvédő, betegségmegelőző programoknak ne lenne értelme. Statisztikai összefüggést találtunk az iskola településtípusa (fővárosi és nem fôvárosi) és a szerzett tapasztalatokra adott válaszok között: a budapesti középiskolásoknak inkább pozitív tapasztalatai vannak a programokat illetően $(\mathrm{p}=0,002)$, kevésbé tartják unalmasnak $(\mathrm{p}<0,001)$, és inkább látják ezeknek a programoknak az értelmét ( $\mathrm{p}=$ $0,033)$. Ezt az eredményt erősíti meg az is, hogy a budapesti diákok a programok után inkább meg szokták vitatni egymás között a hallottakat, mint a nem budapestiek $(\mathrm{p}=0,019)$.

$\mathrm{Az}$ iskolai közösségi szolgálat egy jó keret lehetne a kortárs egészségvédő és betegségmegelőző programok szervezésében, emiatt a felmérésünk erre vonatkozó kérdéseket is tartalmazott. A teljes minta 70,2\%-a rendelkezett már valódi tapasztalatokkal az IKSZ-ról, közel egyötödük $(18,7 \%)$ már teljesítette is mind az ötven órát. A részt vevő diákok többségének $(73,4 \%)$ inkább pozitív tapasztalatai voltak. Erős statisztikai bizonyítékot kaptunk arra, hogy az IKSZ-program nagyobb hányadát teljesítők inkább pozitívan értékelték az önkéntes munkát $(\mathrm{p}<0,001)$. A középiskolás diákok többsége szívesen végezné az iskolai közösségi szolgálatot fiatalabb korcsoportok körében: legszívesebben óvodásokkal (52,7\%) és kisiskolásokkal (47,9\%) foglalkoznának. Statisztikailag erős bizonyítékot kaptunk arra vonatkozóan, hogy a lá- 
Korcsoport-preferencia középiskolás fiúk és leányok körében (\%), $\mathrm{N}=897$

\begin{tabular}{llll}
\hline & Fiúk & Leányok & $\mathrm{p}$-érték \\
\hline $\begin{array}{l}\text { Óvodásokkal szívesen foglalkozók } \\
\text { aránya }\end{array}$ & $34,7 \%$ & $66,8 \%$ & $\mathrm{p}<0,001$ \\
$\begin{array}{l}\text { Kisiskolásokkal szívesen } \\
\text { foglalkozók aránya }\end{array}$ & $41,0 \%$ & $53,3 \%$ & $\mathrm{p}<0,001$ \\
$\begin{array}{l}\text { Felsőtagozatosokkal szívesen } \\
\text { foglalkozók aránya }\end{array}$ & $26,6 \%$ & $21,5 \%$ & $\mathrm{p}=0,042$ \\
$\begin{array}{l}\text { Kortársakkal szívesen foglalkozók } \\
\text { aránya }\end{array}$ & $48,5 \%$ & $31,0 \%$ & $\mathrm{p}<0,001$ \\
$\begin{array}{l}\text { Felnőttekkel szívesen foglalkozók } \\
\text { aránya }\end{array}$ & $24,6 \%$ & $17,9 \%$ & $\mathrm{p}=0,009$ \\
$\begin{array}{l}\text { Idősekkel szívesen foglalkozók } \\
\text { aránya }\end{array}$ & $18,0 \%$ & $21,7 \%$ & $\mathrm{p}=0,102$ \\
\hline
\end{tabular}

nyok szívesebben foglalkoznának a kisebbekkel, ugyanakkor a felső tagozatosok, kortársak és a nem időskorú felnőttek esetében fordított a helyzet, hiszen ott a fiúk magasabb százalékban jelölték be ezeket a korcsoportokat (1. táblázat).

A válaszadó középiskolások 82,8\%-a szerint az IKSZ kapcsán megjelenő „segíteni akarás” jó. Az erre adott válaszokat befolyásolta a kérdezett neme, hiszen erős statisztikai bizonyítékot találtunk arra, hogy a lányok inkább adnak erre pozitív választ, mint a fiúk $(\mathrm{p}<0,001)$. Nem volt összefüggés ugyanakkor a kérdezettek iskolájának helyszínével (fóvárosi/nem fóvárosi). A válaszadó diákok mindössze 54,0\%-a szerint jár együtt az IKSZ hasznos ismeretszerzéssel. Ennél a változónál a válaszadó neme ( $\mathrm{p}=0,008)$ és iskolájának településtípusa (föváro$\mathrm{si} / \mathrm{nem}$ fóvárosi) is $(\mathrm{p}=0,036)$ statisztikailag alátámasztható különbséget adott. A lányok és a fóvárosiak inkább gondolják azt, hogy az IKSZ révén hasznos ismeretekre tettek szert.

Arra a kérdésünkre, hogy a kitöltő szívesen részt venne-e az IKSZ keretén belül egyetemi hallgatók segítségével kisebb gyermekek részére szervezett egészségvédő/ betegségmegelőző programban, a válaszadó diákok több mint egyharmada $(34,2 \%)$ egyértelmúen pozitív választ adott, teljesen elutasító körülbelül egyötödük (19,0\%) volt. A válaszokat befolyásolta a kérdezett neme $(\mathrm{p}<0,001)$, az iskola településtípusa (fövárosi/nem fövárosi) $(\mathrm{p}=0,013)$, évfolyama $(\mathrm{p}=0,60)$, valamint $\mathrm{az}$, hogy a 2014/2015-ös tanévben vett-e részt egészségvédő témákkal foglalkozó programon $(\mathrm{p}=0,007)$. A lányok, a fóvárosiak, az alacsonyabb évfolyamokra járó, valamint az egészségvédő témájú foglalkozásokon részt vevő diákok inkább pozitív választ adtak erre a kérdésre. A programban a diákok leginkább a hasznos tudás megszerzése (pozitív válaszadók 52,4\%-a, bizonytalanok 43,3\%-a), a munka kreatív jellege (pozitív válaszadók $53,7 \%$-a, bizonytalanok $41,2 \%$-a), valamint a kisgyermekeknek átadott hasznos tudás (pozitív válaszadók $54,4 \%$-a, bizonytalanok $35,0 \%$-a) miatt vennének részt.
A bizonytalan vagy elutasító válaszok mögött leggyakrabban a tapasztalathiány (bizonytalanok esetében 51,9\%-uk, elutasítók 29,2\%-a), a fegyelmezetlen gyermekek miatti (bizonytalanok esetében $26,9 \%$-uk, elutasítók 21,1\%-a), valamint a felelősségtől való félelem (bizonytalanok esetében 24,0\%-uk, elutasítók 18,1\%-a) jelent meg.

\section{Megbeszélés}

Eredményeinket összegezve az alábbi fontosabb megállapításokat tesszük:

- Az egyik legfogékonyabb és legfontosabb életszakaszban sok fiatal nem vesz részt iskolai tanóra keretei között vagy azon kívüli egészségvédelemmel, tudatos betegségmegelőzéssel foglalkozó programokban, annak ellenére, hogy döntő hányaduk szerint ezeknek a programoknak pozitív hatása lehet a jövőjükre, életvitelükre.

- A budapesti diákok szívesebben vesznek részt iskolai tanórai és tanórán kívüli prevenciós programokban, mint a nem fóvárosi diákok. A fóvárosi diákok általában pozitívabb tapasztalatokkal és ezáltal jobb véleménnyel bírnak ezekről a programokról.

- A diáklányok sokkal pozitívabb attitűdökkel rendelkeznek az egészségvédelemmel, betegségmegelőzéssel foglalkozó programokat, illetve az IKSZ-et illetően.

- Míg a lányok a fiatalabb, addig a fiúk inkább az idősebb korcsoportokkal foglalkoznának szívesebben az IKSZ-tevékenységük során.

- Az egészségvédelemmel, egészségtudatossággal, betegségmegelőzéssel foglalkozó programok jellemzően a hagyományos oktatási módszerekre építenek, miközben ez köztudottan nem feltétlenül hatékony a fiatal generációk esetében, hiszen az Y és Z generációk egészen másfajta, újszerü, sokkal interaktívabb, élményközpontú tudásátadási módszertant igényelnének.

- A válaszadó középiskolás diákok nagy hányada egyértelműen nyitott arra, hogy az iskolai közösségi szolgálat keretén belül a kisebbekkel (különösen óvodásokkal) közös sport- vagy egyéb szabadidős tevékenységet folytasson. Több mint négyötödük szerint alapvetően jó a segítő szándék.

- A középiskolás diákok többségének inkább pozitív tapasztalatai vannak az iskolai közösségi szolgálat tevékenységéról. Fontos ugyanakkor megjegyeznünk, hogy a válaszadóknak közel fele szerint egyébként értelmetlen a közösségi munka.

- A felvázolt, de nem nevesített TANTUdSZ programban (vagyis, hogy szívesen részt venne-e IKSZ keretén belül, kisebb gyermekek részére, egyetemi hallgatók segítségével szervezett egészségvédő/betegségmegelőző programban) a diákok több mint egyharmada nagyon szívesen részt venne, ugyanakkor nagyon sokan adtak bizonytalan választ. Hozzávetőleg minden ötödik diák egyértelmüen elutasitó volt. A bizonytalan vá- 
laszok, valamint az elutasítás mögött legtöbben a nem elegendő tapasztalatot, a kisebb gyermekek fegyelmezetlenségét, valamint a felelősségtől való félelmet jelölték be.

Hiánypótló kérdőíves felmérésünk kutatási korlátját leginkább a nem reprezentatív minta jelenti. Külön ki kell emelnünk, hogy mintánkban felülreprezentáltak voltak a fóvárosi diákok és a gimnazisták. Tekintettel a téma fontosságára, a jövőben felmérésünk országos, lehetőség szerint reprezentatív kutatási szinten történő folytatását tervezzük.

Anyagi támogatás: A kutatás a Magyar Tudományos Akadémia által támogatott TANTUdSZ program részeként valósult meg.

Szerzôi munkamegosztás: F. H. J.: A kérdőív kérdéseinek összeállítása, statisztikai elemzés, a kézirat első változatának elkészítése, majd a beérkezett javaslatok utáni javítása. M. D.: A kérdőív kérdéseinek összeállítása, engedélyek beszerzése, a kézirat szövegének javítása. M. G.: Az elektronikus kérdőív megszerkesztése, adatok konvertálása, a kézirat szövegének javítása. G. E.: Kérdőív kérdéseinek összeállítása, adatok konvertálása, adatelemzés. F. R.: Kérdőív kérdéseinek összeállítása, a kézirat szövegének javítása, szakirodalom. D. S.: Kérdőív kérdéseinek összeállítása. H. Zs.: Kérdőív kérdéseinek összeállítása, adatok konvertálása. N. H. E.: Kérdőív javítása. S. K. Zs.: Kérdőív javítása, minta BKI-kérdőív javítása. B. K. I., F.-N. L. L. K., U. V.: Kérdőív javítása, minta szervezése. M. E.: kérdőív javítása, próbatesztelés. Sz. T. T.: Kérdőív javítása, lekérdezés, UV-kérdőív javítása, le- kérdezés. K. A.: Kérdőív kérdéseinek összeállítása. F. A.: Kérdőív javítása, engedélyek beszerzése, a kézirat szövegének javítása, kutatói csoport vezetése. A cikk végleges változatát valamennyi szerző jóváhagyta.

Érdekeltségek: A szerzőknek nincsenek érdekeltségeik.

\section{Irodalom}

[1] Pikó, B., Kopp, M.: Foreword - From the biopsychosocial model to behavioral medicine. [Előszó - A biopszichoszociális szemlélettől a magatartásorvoslásig.] Magyar Tudomány, 2003, 11, 1348-1351. [Hungarian]

[2] Székely, A., Susánszky, É., Ádám, Sz.: Risk behaviour of youngsters. In: Székely, L. (ed.): Hungarian Youth 2012. [Fiatalok kockázati magatartása. In: Székely, L. (szerk.): Magyar Ifjúság, 2012.] Magyar Közlöny Lap- és Könyvkiadó, Budapest, 2013. [Hungarian]

[3] Németh, Á., Költó, A. (eds.): Health and lifestyle of young teenagers - 2010. [Serdülőkorú fiatalok egészsége és életmódja 2010.] OGYEI, Budapest, 2011. [Hungarian]

[4] Pénzes, M., Balázs, P.: Adolescents' perceptions on the effectiveness of tobacco control policies. [Dohányzásellenes intézkedések hatékonyságának megítélése serdülők körében.] Egészségtudomány, 2003, 57(1), 57-74. [Hungarian]

[5] Feith, H. J., Melicher, D., Falus, A.: Instead of an afterword, about the TANTUdSZ program. In.: Falus, A. Melicher, D. (eds.): Colourful health awareness - Understand it, do it, like it! [Utószó helyett a TANTUdSZ programról. In: Falus, A., Melicher, D. (szerk.): Sokszínú egészségtudatosság - Értsd, csináld, szeresd!] SpringMed Kiadó, Budapest, 2015. [Hungarian]

(Feith Helga Judit dr., Budapest, Vas utca 17., 1088 e-mail cím: feith@se-etk.hu) 